\title{
Prevalence of Hepatitis C Virus Genotypes in Pakistan: Current Scenario and Review of Literature
}

\author{
Aleena Haqqi, ${ }^{1}$ Rimsha Munir, ${ }^{2,3}$ Muhammad Khalid, ${ }^{3}$ Muhammad Khurram,, Muhammad Zaid, ${ }^{1}$ \\ Muhammad Ali, ${ }^{1}$ Zaheer Hussain Shah, ${ }^{1}$ Haroon Ahmed, ${ }^{4}$ and Muhammad Sohail Afzal ${ }^{1}$
}

\begin{abstract}
Hepatitis $\mathrm{C}$ virus (HCV) is a major public health concern globally, resulting in liver-related complications. Approximately 6\% population of Pakistan is infected with $\mathrm{HCV}$. HCV is error prone, due to which it is classified into 7 genotypes and 67 subtypes. HCV genotype determination is critical for treatment and therapy response. In this study, 3,539 samples were collected from 2015 to 2019 from all over Punjab. RNA was extracted from samples using QIA Amp Viral RNA MINI kit (Qiagen, Germany) and viral genotyping was performed. Furthermore, a systemized literature search (2009-2018) was done to analyze the HCV genotype distribution pattern in Pakistan. In Punjab, genotype 3a $(86.46 \%)$ is most prevalent, followed by untypable $(7.17 \%)$ and genotype $1 \mathrm{a}(3.84 \%)$ and $3 \mathrm{~b}(1.04 \%)$. Mixed genotype constitutes only $0.67 \%$ of total infections. Genotype 2a, 2b, 3c, and 4 were found to be rare. Data available from literature review when compiled showed that HCV genotype 3a (58.16\%) was predominant in Pakistan, followed by genotypes $3 \mathrm{~b}(9.05 \%)$, 2a (6.70\%), $1 \mathrm{a}(6.22 \%)$, and $1 \mathrm{~b}(2.39 \%)$. The frequency of mixed genotypes was found to be $4 \%$ and $12 \%$ of untypable HCV variants. This study highlights the HCV genotype distribution pattern in different regions of Pakistan. Therapy response and disease management depend on genotype, so HCV genotype determination is crucial. In Pakistan, the most prevalent genotype is $3 \mathrm{a}$, followed by untypable genotype. Both interferon and sofosbuvir are effective against genotype $3 \mathrm{a}$, but treatment with sofosbuvir has comparatively high sustained virological response, less adverse effects, and more tolerability.
\end{abstract}

Keywords: epidemiology, HCV, genotype, public health, Pakistan

\section{Introduction}

$\mathbf{H}$ EPATITIS $\mathrm{C}$ Is a considerable public health challenge worldwide (4). Hepatitis C virus (HCV) precisely affects the liver causing chronic hepatitis and hepatocellular carcinoma (HCC), resulting in morbidity and mortality worldwide (23,72). According to an estimate, almost 200 million people are thought to be infected with $\mathrm{HCV}$ around the globe $(5,23,63)$. Worldwide, roughly 350,000 deaths occur due to pathological hepatocellular complications caused by $\mathrm{HCV}(5,72)$. High fatality rate of HCV-infected individuals can be correlated to the fact that persistent and untreated $\mathrm{HCV}$ infections can lead to the development of HCC (58). One of the major risk factors for the development of HCC includes $\mathrm{HCV}$ infections and the most prevalent $\mathrm{HCV}$ genotype in HCC patients was $1 \mathrm{~b}(60)$. The progression rate of $\mathrm{HCV}$ chronic hepatitis to the development of HCC seems to depend on various host and environmental factors, that is, age, gender, alcohol consumption, viral load, and viral variants (57).

African and east Mediterranean regions have the highest rate of $\mathrm{HCV}$ prevalence, whereas the regions having minimal HCV prevalence $(<2 \%)$ are Americas, Australia, and Western Europe. Although the prevalence of HCV is different for individual countries in Asia, its combined prevalence is estimated to be slightly more than $2 \%$. Egypt surpasses other nations, being the country bearing the highest HCV burden of $\sim 14 \%$ (73). Of the total population of Pakistan, $6 \%$ individuals are infected with $\mathrm{HCV}$, suggesting that viral hepatitis is alarmingly high in general population (48). An estimate suggests that $\sim 10$ million individuals in Pakistan are infected with $\mathrm{HCV}$, making it a state with second highest HCV burden after Egypt (7). In developing countries like Pakistan, HCV burden is continually on the rise,

\footnotetext{
${ }^{1}$ Department of Life Sciences, School of Science, University of Management and Technology (UMT), Lahore, Pakistan.

${ }^{2}$ Cancer Biology Lab, MMG, University of the Punjab, Lahore, Pakistan.

${ }^{3}$ Hormone Lab, Lahore, Pakistan.

${ }^{4}$ Department of Biosciences, COMSATS Institute of Information Technology, Islamabad, Pakistan.
} 
significantly due to lack of awareness, unsafe blood transfusion, improper surgical and dental procedures, use and reuse of unsterilized syringes and medical equipment, and unsafe barber, tattooing, and nose/ear piercing tools $(4,8,75)$. Prevalence of HCV in high-risk groups is $66 \%$, which is much higher than the prevalence in general population (3.13-23.83\%) and healthy blood donors (1.05-20.8\%) (4,73).

$\mathrm{HCV}$ belongs to family Flaviviridae and is a member of genus Hepacivirus (35). It is a positive single-stranded RNA virus comprising $9.6 \mathrm{~kb}$ genome encoding a single polypeptide $(31,43)$. Replication executed by RNA-dependant RNA polymerase is error prone, which results in severe heterogeneity of HCV $(19,71)$. According to an estimate, $10^{-2}$ mutations occur per nucleotide per year (64).

$\mathrm{HCV}$ genome is classified into 7 major genotypes based on its phylogenetic and sequence analysis; genotypes are further classified into 67 recognized subtypes and 20 provisional subtypes (52). Genotype 1 and genotype 3 are distributed worldwide, accounting $46 \%$ and $30 \%$ of all HCV infection, respectively (52). In European countries, genotype 1 is most prevalent followed by genotype 2 and genotype 3 (58). South Asia accounts for most (75\%) cases of genotype 3 . East Asia is endemic with genotype 2 and genotype 6 . Genotype 5 is very rare and most cases are found to be present in Eastern and Southern Africa. In Middle Eastern non-Arab countries (Cyprus, Israel, Iran, and Turkey), genotype 1 accounts for most of the cases, whereas Arabian countries are endemic with genotype 1 and 4 (70).

In Pakistan, the most predominant $\mathrm{HCV}$ genotype is $3 \mathrm{a}$ and $3 \mathrm{~b}$ followed by $1 \mathrm{a}, 2 \mathrm{a}$, and untypable genotype $(6,7,18,37)$. In Khyber Pakhtunkhwa (KPK), Punjab, and Sindh, genotype $3 \mathrm{a}$ and $3 \mathrm{~b}$ were found to be most prevalent, whereas most of the patients from Baluchistan were infected with genotype $1 \mathrm{a}$ and $2 \mathrm{a}$ (37).

Determination of HCV genotype is critical for deciding the clinical management and predicting the prognosis of $\mathrm{HCV}$ infection. Genotype is the fundamental predictive parameter for sustained virological response (SVR) (81). In Pakistan previously, the main option for treatment was interferon (IFN) based on its ease of availability, low cost, and high SVR against particular genotypes (4). Other options include pegylated IFN (PEG-IFN), ribavirin, or their combinations $(10,67,79)$. Advancement in the development of direct-acting antivirals (DAA) has revolutionized the treatment approach, having high SVR with lesser side effects and short duration. The Asian Pacific Association for the study of the Liver guidelines have emphasized on the use of Solvadi (sofosbuvir-NS5B inhibitor) for treating viral genotypes GT1, GT2, and GT3 (4).

As the genotype determination is crucial for the selection of therapeutic strategies and duration, in such circumstances, there is a need to analyze the HCV genotype distribution pattern in different regions of Pakistan to precisely design a treatment strategy according to viral genotype.

\section{Methodology}

\section{Sampling}

The study was conducted from 2015 to 2019. A total of 3,539 (Males: 1,609 [45.46\%], females: 1,930 [54.53\%], $\mathrm{M} / \mathrm{F}$ ratio: $1: 1.19$ ) samples from Punjab were genotyped for the study with informed and written consent of each patient.
We excluded the subjects with comorbidities, pregnant women, and the participants younger than 7 years. This study was approved by the ethical committee of Department of Life Sciences, University of Management and Technology, and Lahore Clinical Laboratory and Research Centre, Lahore, Pakistan.

\section{HCV qualitative test}

Serum separated from the blood samples collected from 3,539 hepatitis C patients was subjected to RNA extraction using QIA Amp viral RNA MINI kit (Qiagen, Germany). All the steps of HCV quantitative test were performed according to the protocol provided by the manufacturer. In a reaction mixture of $20 \mu \mathrm{L}$, reverse transcription of $5^{\prime}$ untranslated region ( $5^{\prime}$ UTR) of extracted viral RNA was carried out using reverse transcriptase enzyme of MoloneyMurine Leukemia Virus (M-m LVRTase; Invitrogen), at $37^{\circ} \mathrm{C}$ for $60 \mathrm{~min}$. Polymerase chain reaction (PCR) of first round was carried out using antisense and outersense primers to amplify the complementary DNA (cDNA) of $5^{\prime}$ UTR (55). Second round of nested PCR was completed using inner primers. Thermus aquaticus (Taq) DNA polymerase was used to amplify template DNA in both first and second round of PCR. The amplified product produced in first round of PCR was used as a template in second round of nested PCR. A Gel documentation system was used to visualize the amplified PCR products of second round, when they were made to run on $2 \%$ agarose gel electrophoresis. Reconfirmation of all the PCR-positive samples was done on Real-Time Rotor Gene Equipment (Qiagen) using HCV RG-RT PCR kit.

\section{HCV genotyping}

All HCV-positive samples were subjected to genotyping. Generally, six distinct genotypes of $\mathrm{HCV}$ can be/were identified using the method of Ohno et al. (55). Two hundred units of M-mL Virus RT was used to carry out the process of reverse transcription for the synthesis of cDNA using viral RNA $(10 \mu \mathrm{L})$ as a template. In first round of PCR, forward primer (5'-GGGAGGTCTCGTAGACCGTGCACC ATG-3') and reverse primer (5'-GAGACGGGTATAGTA CCCCATGAGAGTCGGC-3') were used to amplify $5 \mu \mathrm{L}$ of synthesized cDNA. For each first-round PCR sample, two second-round PCRs were performed. One second round was carried out with mix 1, composed of primers for genotype $1 \mathrm{~b}, 2 \mathrm{a}, 2 \mathrm{~b}$, and $3 \mathrm{~b}$. The other second round was completed with mix 2, which consisted of genotype-specific primers for 3a, 4, 5a, 1a, and 6a. Taq DNA polymerase (Invitrogen) was used to amplify the template cDNA in all PCRs. Amplified products of second round of PCR was visualized on gel documentation system after they were subjected to electrophoresis on $2 \%$ agarose gel with a DNA marker of $100 \mathrm{bp}$ ladder. HCV genotype of each sample was confirmed by comparing the obtained band size with the HCV genotype-specific PCR band.

\section{Literature review}

A systematic review of literature was conducted on PubMed, PakMedinet, and Google scholar using the following keywords: "HCV, Genotype, Prevalence, and Pakistan." 
Table 1. Hepatitis C Virus Genotype Distribution in Punjab (2015-2019)

\begin{tabular}{|c|c|c|c|c|c|c|c|c|c|c|c|c|c|}
\hline \multirow[b]{2}{*}{ Year } & \multirow[b]{2}{*}{ Gender } & \multirow{2}{*}{$\begin{array}{c}\text { Age average } \\
\pm(S D)\end{array}$} & \multicolumn{10}{|c|}{ Genotype (N) } & \multirow[b]{2}{*}{ Total } \\
\hline & & & $1 a$ & $1 b$ & $2 a$ & $2 b$ & $3 a$ & $3 b$ & $3 c$ & $4 a$ & Mixed & Untypable & \\
\hline \multirow{3}{*}{2015} & Male & $44 \pm 13.60$ & 35 & 1 & 1 & 1 & 545 & 12 & 2 & 1 & 8 & 10 & 616 \\
\hline & Female & $44 \pm 12.60$ & 20 & - & - & - & 633 & 14 & - & 1 & 7 & 19 & 694 \\
\hline & Total & $44 \pm 13.08$ & 55 & 1 & 1 & 1 & 1,178 & 26 & 2 & 2 & 15 & 29 & 1,310 \\
\hline \multirow{3}{*}{2016} & Male & $42 \pm 13.61$ & 18 & - & - & - & 403 & 4 & - & 2 & 3 & 8 & 438 \\
\hline & Female & $45 \pm 11.97$ & 17 & - & - & 1 & 494 & 6 & 1 & - & 2 & 10 & 531 \\
\hline & Total & $43 \pm 12.80$ & 35 & - & - & 1 & 897 & 10 & 1 & 2 & 5 & 18 & 969 \\
\hline \multirow[t]{3}{*}{2017} & Male & $45 \pm 21.58$ & 22 & 3 & - & 1 & 379 & - & - & - & 3 & 84 & 492 \\
\hline & Female & $46 \pm 12.70$ & 16 & 11 & 1 & - & 477 & 1 & - & 1 & 1 & 101 & 609 \\
\hline & Total & $45 \pm 12.83$ & 38 & 14 & 1 & 1 & 856 & 1 & - & 1 & 4 & 185 & 1,101 \\
\hline \multirow[t]{3}{*}{2018} & Male & $44 \pm 12.04$ & 2 & - & - & - & 21 & - & - & - & - & - & 23 \\
\hline & Female & $42 \pm 14.78$ & 3 & - & - & - & 33 & - & - & - & - & - & 36 \\
\hline & Total & $43 \pm 13.80$ & 5 & - & - & - & 54 & - & - & - & - & - & 59 \\
\hline \multirow[t]{3}{*}{2019} & Male & $42.25 \pm 14.23$ & 3 & - & - & - & 29 & - & - & - & - & 8 & 40 \\
\hline & Female & $40.26 \pm 13.35$ & - & - & - & - & 46 & - & - & - & - & 14 & 60 \\
\hline & Total & $41.05 \pm 13.82$ & 3 & - & - & - & 75 & - & - & - & - & 22 & 100 \\
\hline
\end{tabular}

$\mathrm{SD}$, standard deviation.

In total, 55 articles were searched for the HCV genotype distribution in different regions of Pakistan; out of these, only 36 studies were included in our study and 19 articles were excluded. The articles that did not have subtypes of $\mathrm{HCV}$ genotypes required for our analysis and articles before 2009 were not included in this study.

\section{Results}

A total of 3,539 HCV-positive samples were genotyped from year 2015 to 2019. Out of 3,539 patient samples, 1,930 $(54.37 \%)$ were female and $1,609(45.62 \%)$ were male (Table 1). The distribution frequency of different viral ge- notypes and subtypes was determined and evaluated as shown in Figure 1. Genotype 3a was found to be the most prevalent genotype $(n=3,060,87 \%)$, followed by untypable genotype $(n=254,7.17 \%)$, genotype 1a $(n=136,3.84 \%)$, and genotype $3 \mathrm{~b}(n=37,1.04 \%)$, whereas very rare number of patients of genotype $2 \mathrm{a}, 2 \mathrm{~b}, 3 \mathrm{c}$, and $4 \mathrm{a}$ was reported to be infected in our study. Co-infection of genotypes accounts $0.67 \%$ of total infected pool, as illustrated in Figure 1.

Available literature analysis from 2009 to 2018 about the frequency distribution pattern of $\mathrm{HCV}$ genotypes in Pakistan showed that genotype $3 \mathrm{a}(58.16 \%)$ was the most prevalent in Pakistan, followed by genotypes $3 \mathrm{~b}(9.05 \%), 2 \mathrm{a}(6.70 \%), 1 \mathrm{a}$ $(6.22 \%)$, and $1 \mathrm{~b}(2.39 \%)$. Genotypes $2 \mathrm{~b}$ and $4 \mathrm{~b}$ accounted

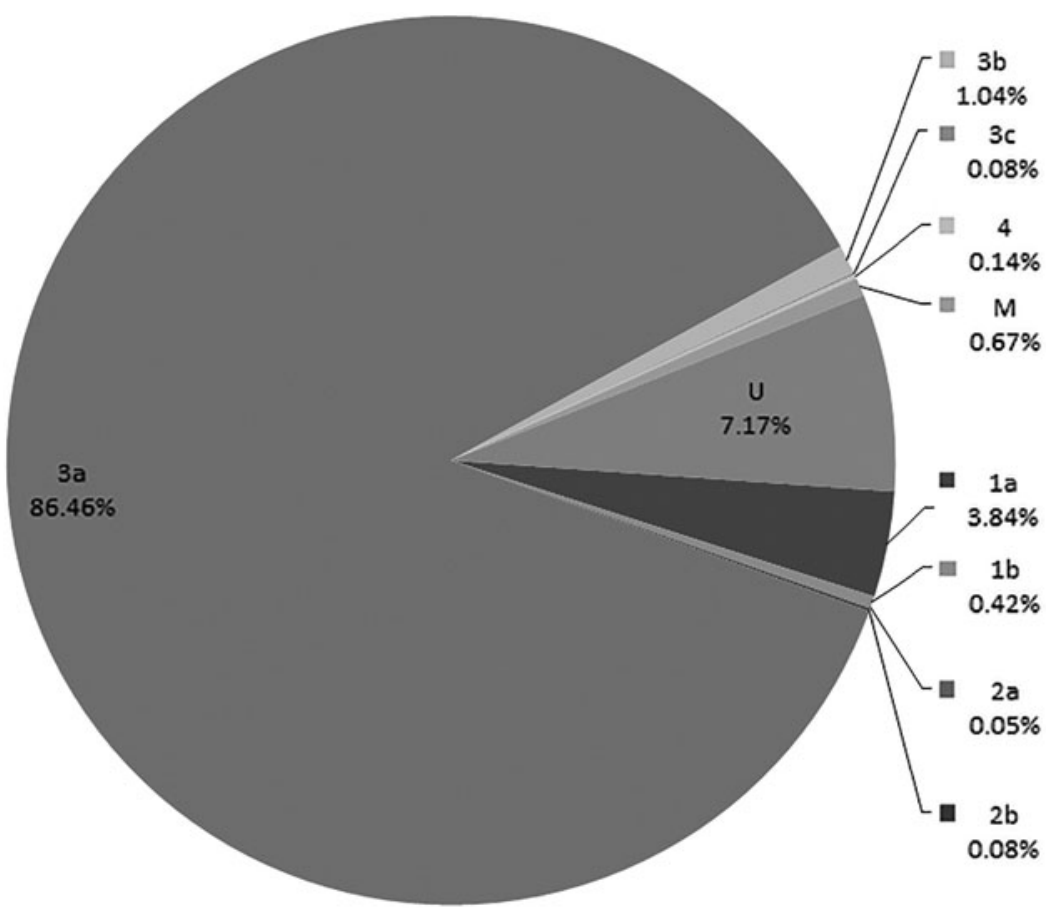

FIG. 1. Results of this study showing HCV genotype distribution in Punjab (2015-2019). HCV, hepatitis C virus. 


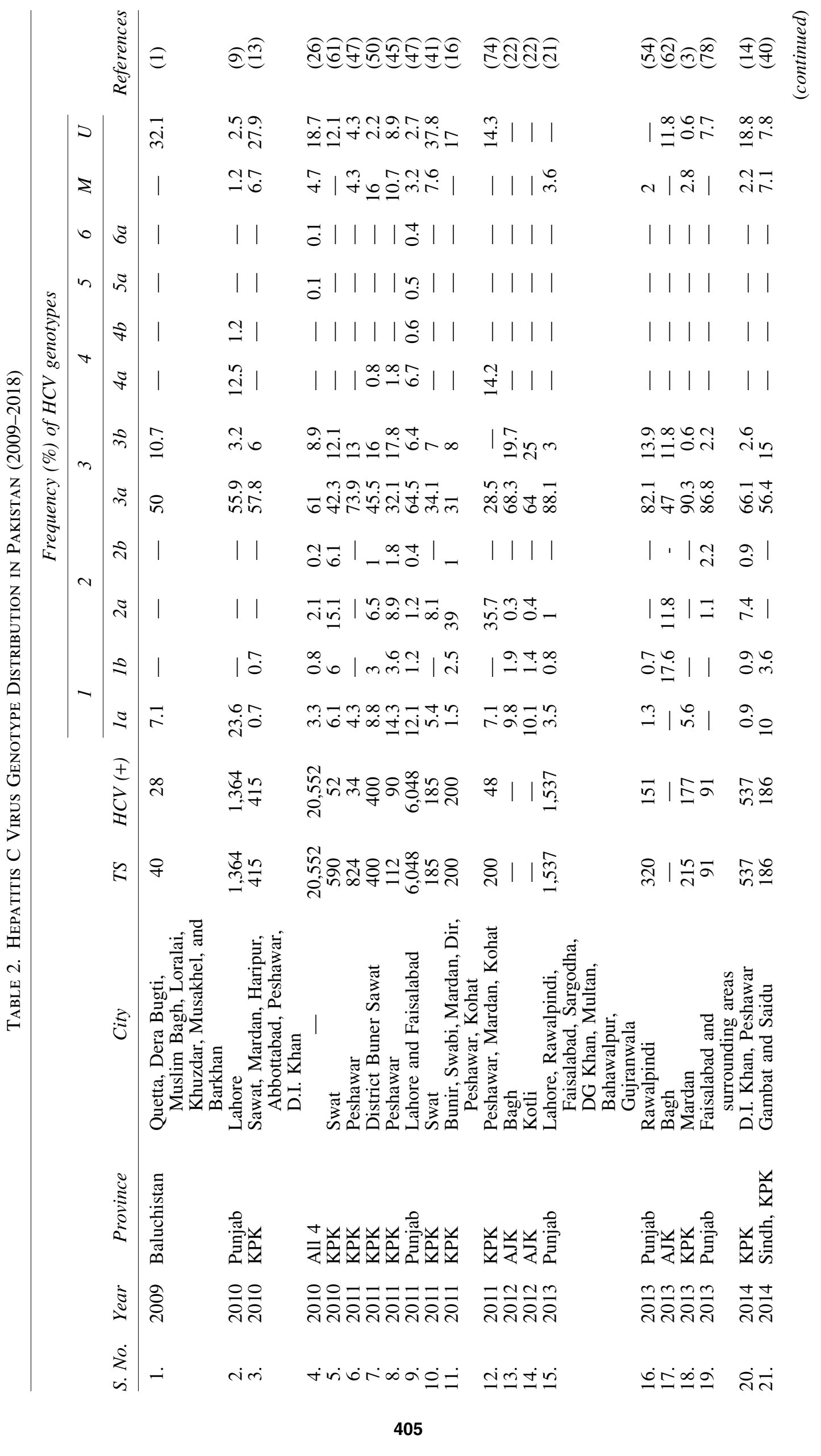




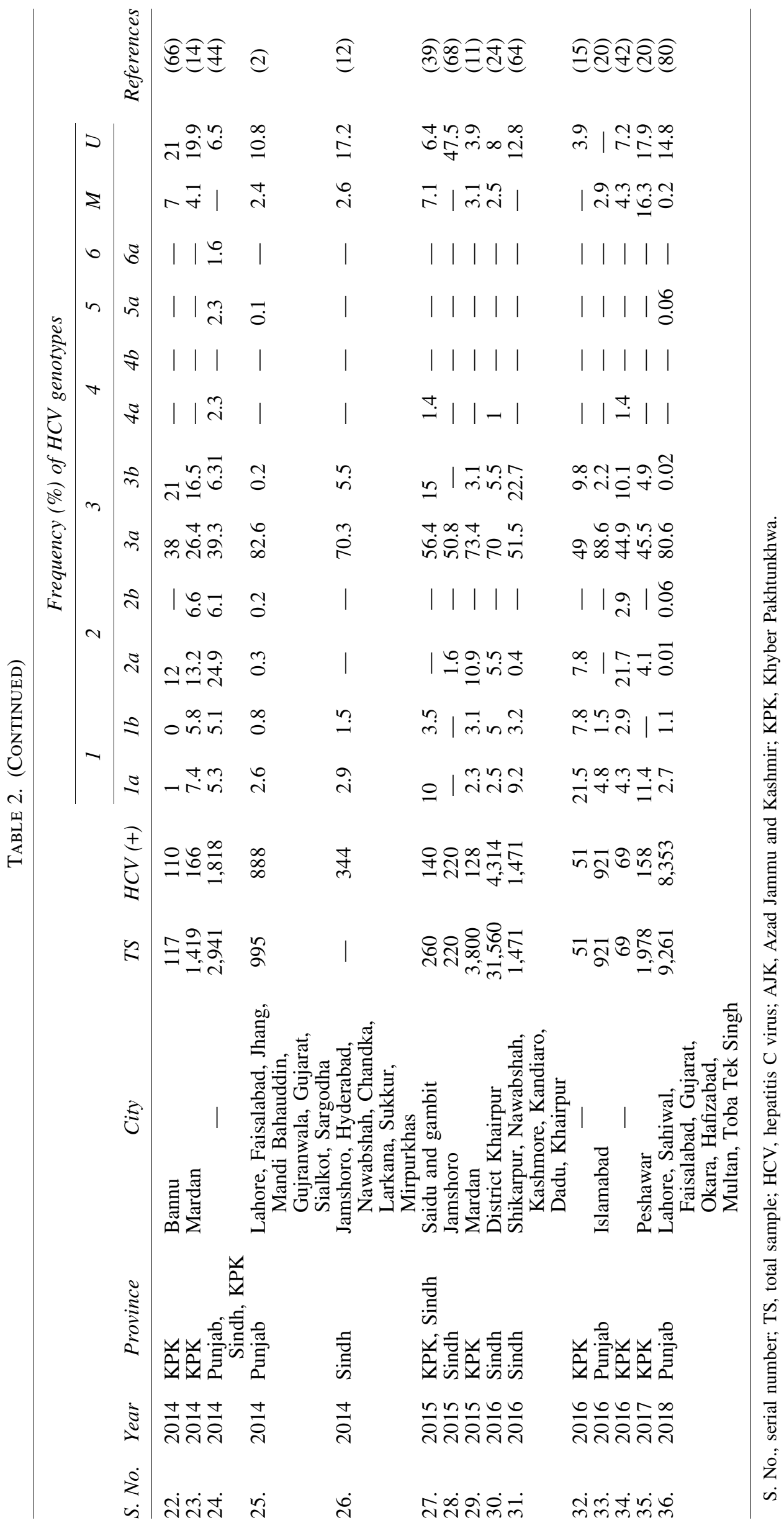




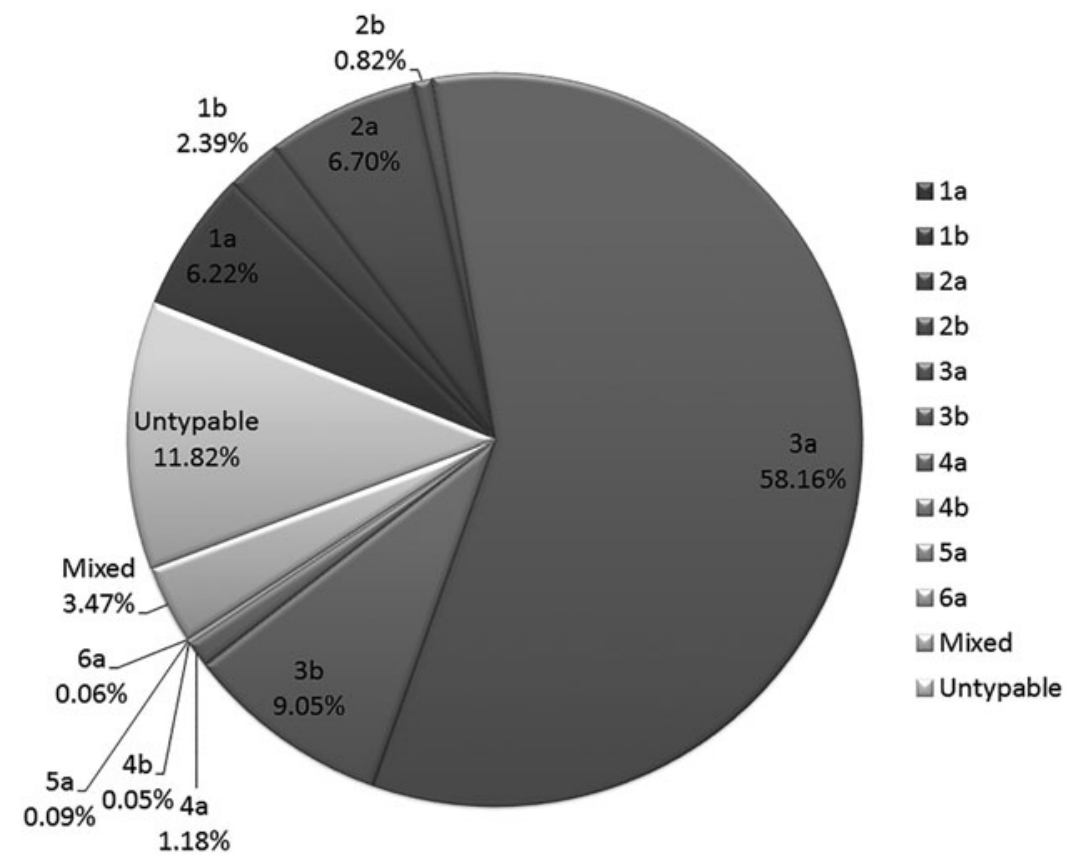

FIG. 2. HCV genotype distribution in Pakistan (2009-2018).

for $0.82 \%$ and $0.05 \%$ of the total sample pool of Pakistan. The frequency of mixed genotypes was found to be $3.47 \%$ and $11.82 \%$ of samples could not be assigned a specific genotype or subtype. Infections due to HCV genotype 5a, $6 \mathrm{a}$, and $4 \mathrm{~b}$ were rare, accounting $0.09 \%, 0.06 \%$, and $0.05 \%$, respectively, as shown in Table 2 and Figure 2.

In Punjab province, a significantly higher frequency of genotype 3a (80.23\%) was observed and the untypable genotype (4.91\%), which was appreciably lower (in frequency) compared to other provinces. The other genotypes followed by genotype $3 \mathrm{a}$ were $1 \mathrm{a}(6.46 \%)$, 3b (3.97\%), 4a (2.45\%), and mixed (1.98\%), as illustrated in Figure 3. Both the ge- notypes $1 \mathrm{~b}$ and $2 \mathrm{a}$ accounted for only $0.76 \%$ and $0.45 \%$ of the total sample pool. Patients diagnosed to be infected with HCV genotype $4 \mathrm{~b}(0.23 \%)$ and $6 \mathrm{a}(0.05 \%)$ were rare.

Of the successfully genotyped samples in Sindh province, $61 \%$ were infected with $3 \mathrm{a}, 21 \%$ were HCV sampleunidentified genotype, $9 \%$ were $3 \mathrm{~b}$, and $4 \%$ were $1 \mathrm{a}$. Two percent samples were infected with $1 \mathrm{~b}$ and $2 \mathrm{a}$ each. Mixed genotypes constitute only $1 \%$ of total samples genotyped, as shown in Figure 4.

The genotype distribution pattern in KPK province was a bit different from other provinces of Pakistan in which genotype 3a (49\%) was followed by genotype $2 \mathrm{a}(12 \%)$ and

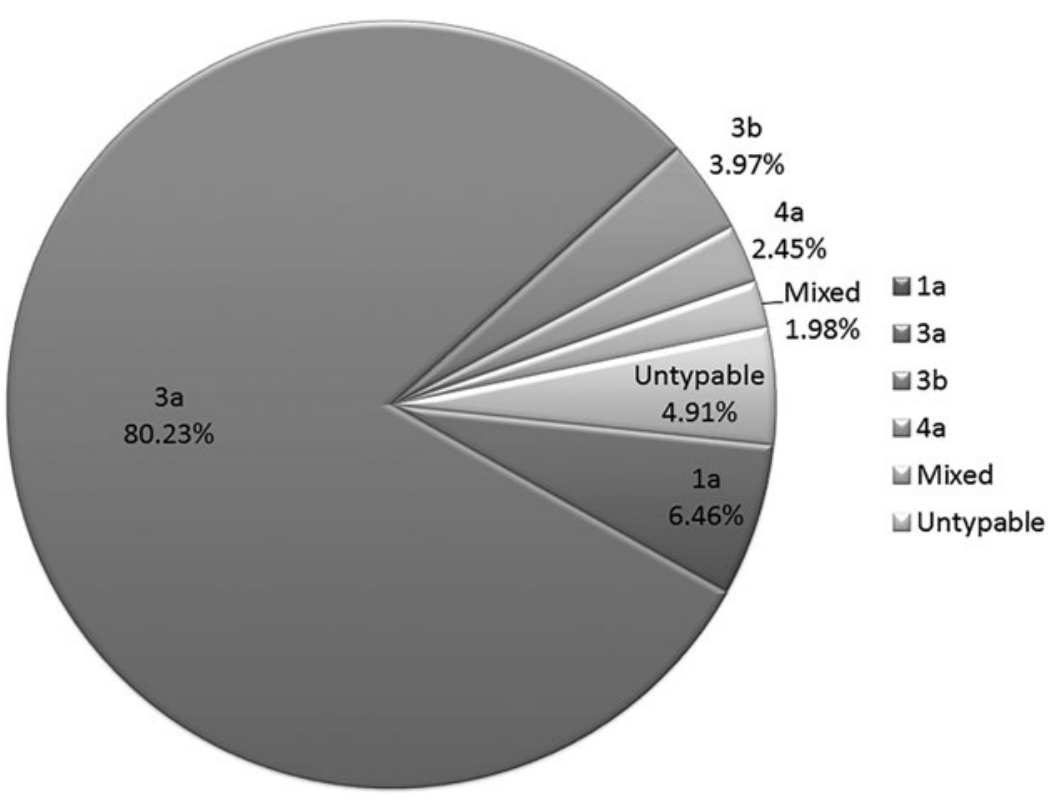

FIG. 3. HCV genotype distribution in Punjab. 


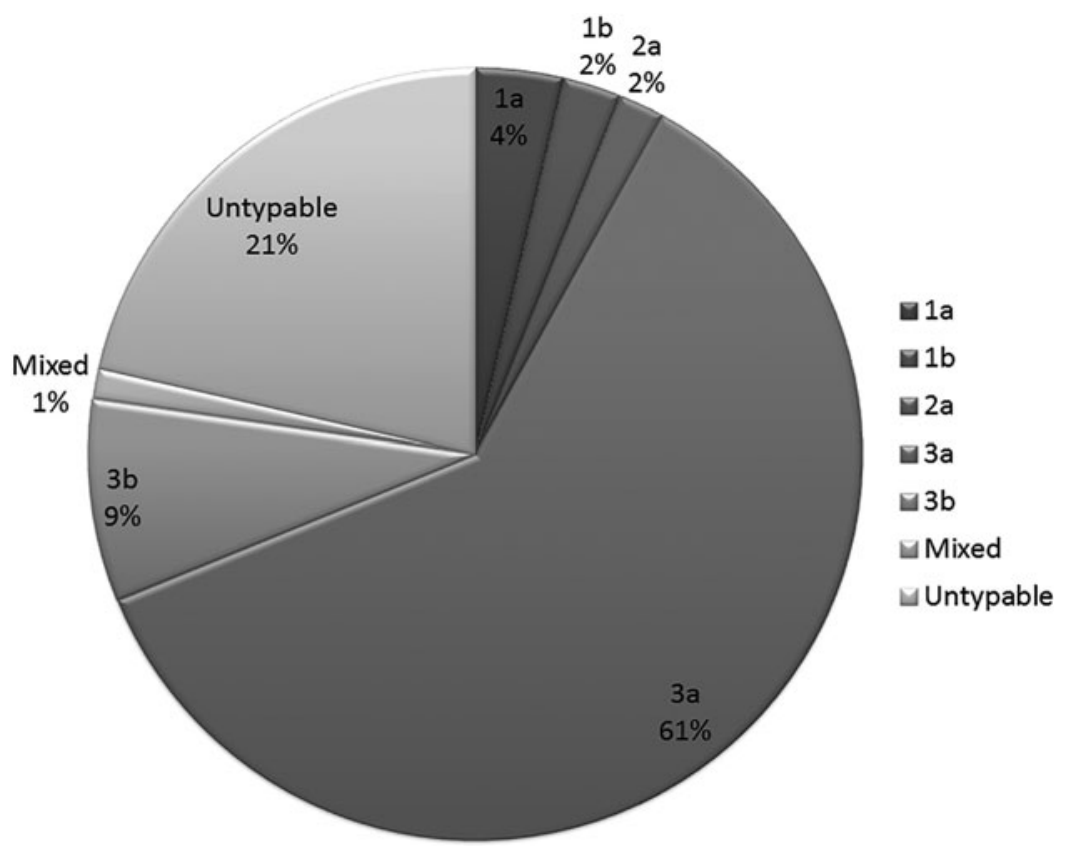

FIG. 4. HCV genotype distribution in Sindh.

untypable genotype (14\%), whereas in other provinces, genotype $2 \mathrm{a}$ was rare. The frequency of all other genotypes were $3 \mathrm{~b}(9 \%)$, 1a (7\%), and mixed (5\%). Genotype 4a and $2 \mathrm{~b}$ account for only $1 \%$ of the total samples genotyped in KPK, as shown in Figure 5.

The data from Baluchistan province are very limited and there was only one study carried out in the year 2009. In this study, only $28 \mathrm{HCV}$-positive samples were genotyped. Study revealed that the highest number of patients were infected with genotype 3 a $(50 \%)$, followed by the unidentifiable genotypes (32\%), and the frequency of two other genotypes $3 \mathrm{~b}$ and $1 \mathrm{a}$ was $11 \%$ and $7 \%$, respectively, as shown in Figure 6.

In Azad Jammu and Kashmir (AJK), HCV genotype 3a is predominant, accounting 59\%. Other genotypes following $3 \mathrm{a}$ were $3 \mathrm{~b}(19 \%), 1 \mathrm{~b}(7 \%), 1 \mathrm{a}(7 \%)$, and $2 \mathrm{a}(4 \%)$. Unidentified genotype was found to be only $4 \%$, whereas infections with genotype 4, 5, and 6 were not found in AJK region of Pakistan, as illustrated in Figure 7.

In all the provinces of Pakistan, genotype $3 \mathrm{a}$ emerged as the most prevalent genotype $(80.23 \%, 61 \%, 59 \%, 49 \%$, and $50 \%$ in Punjab, Sindh, AJK, KPK, and Baluchistan,

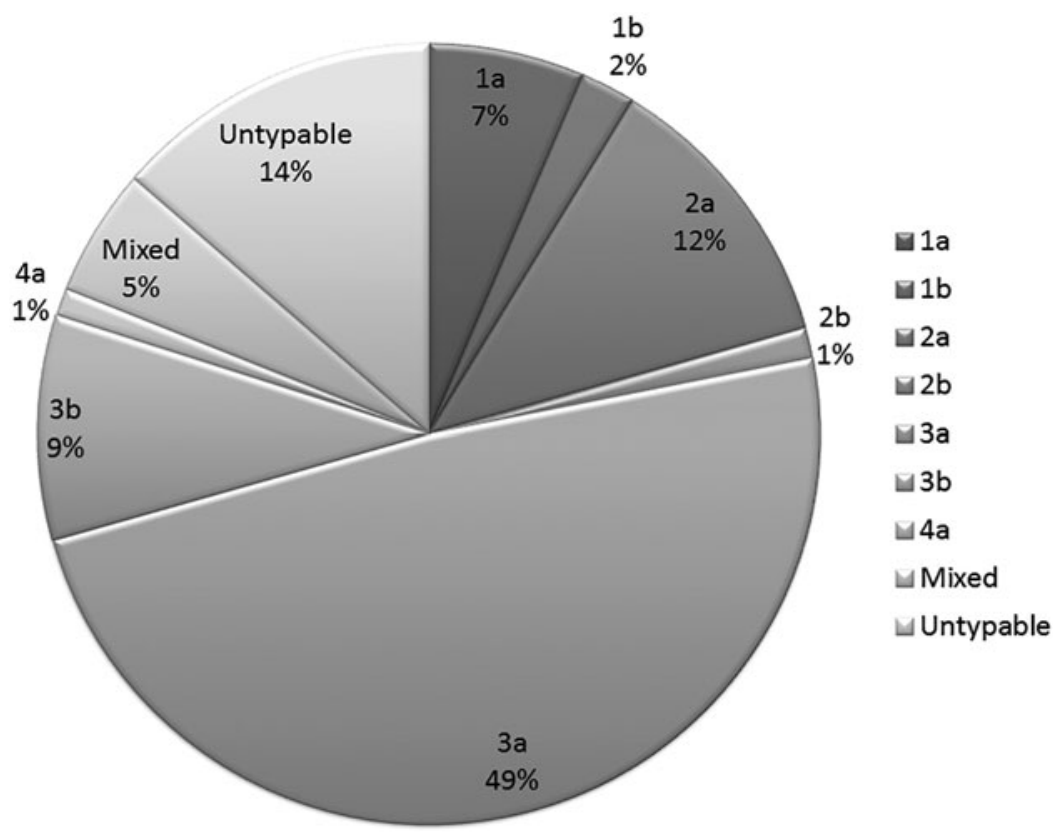

FIG. 5. HCV genotype distribution in Khyber Pakhtunkhwa. 


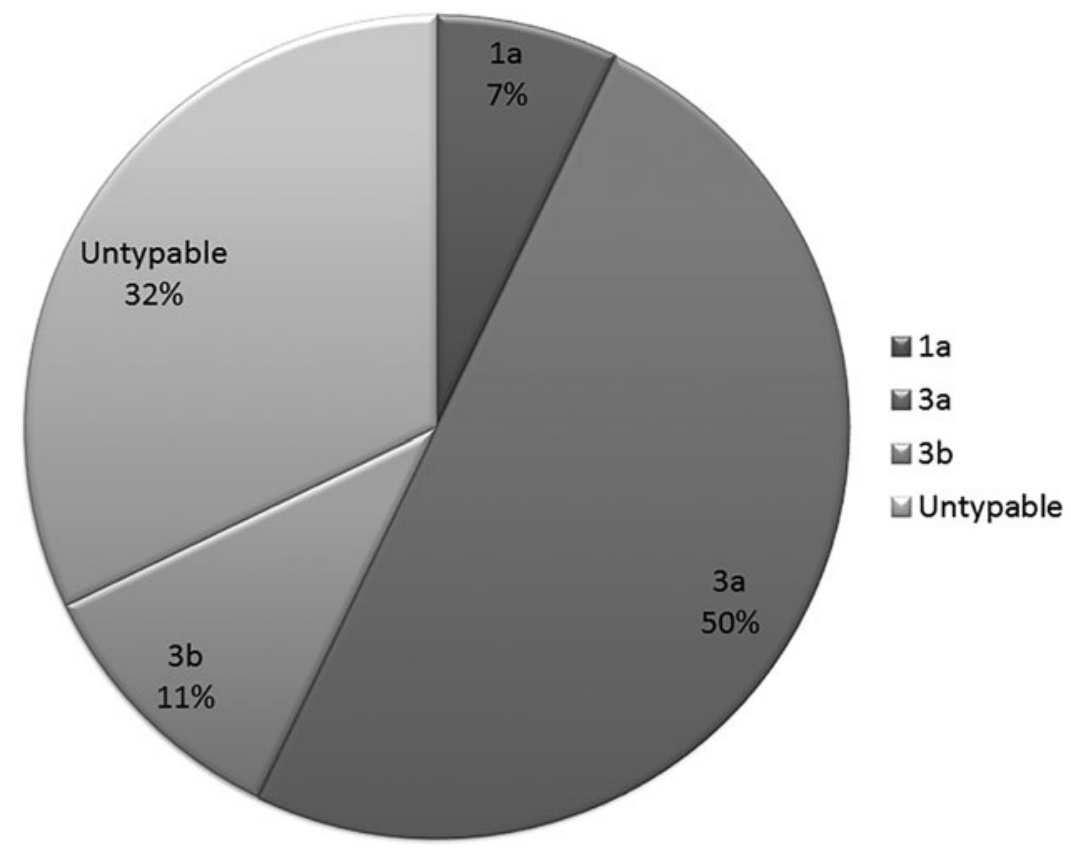

FIG. 6. HCV genotype distribution in Baluchistan.

respectively). The second most prevalent frequency was of untypable genotype $(32 \%, 21 \%$, and $14 \%$ in Baluchistan, Sindh, and KPK, respectively); in contrast, only $4.91 \%$ and $4 \%$ samples from Punjab and AJK were untypable.

\section{Discussion}

It is estimated that $\sim 6 \%$ of population of Pakistan is infected with HCV (48). For the management of incidence of increasing $\mathrm{HCV}$ infections, epidemiological studies that accurately depict the prevalence of $\mathrm{HCV}$ infection and the geographic distribution of $\mathrm{HCV}$ genotypes are crucial. These studies help us strengthen the preventive and therapeutic strategies.

In this study, 3,539 HCV-infected patients were genotyped from all over Punjab. HCV genotype $3 \mathrm{a}$ is the most prevalent in Punjab population, as noticed in this analysis and previous studies $(9,21,47)$. The frequency of genotype 2a-infected patients was found to be decreasing and the frequency of the patients infected with unidentifiable genotype was increasing. Genotype $1 \mathrm{a}$ and $3 \mathrm{~b}$ were also prominent in all the studies published till now.

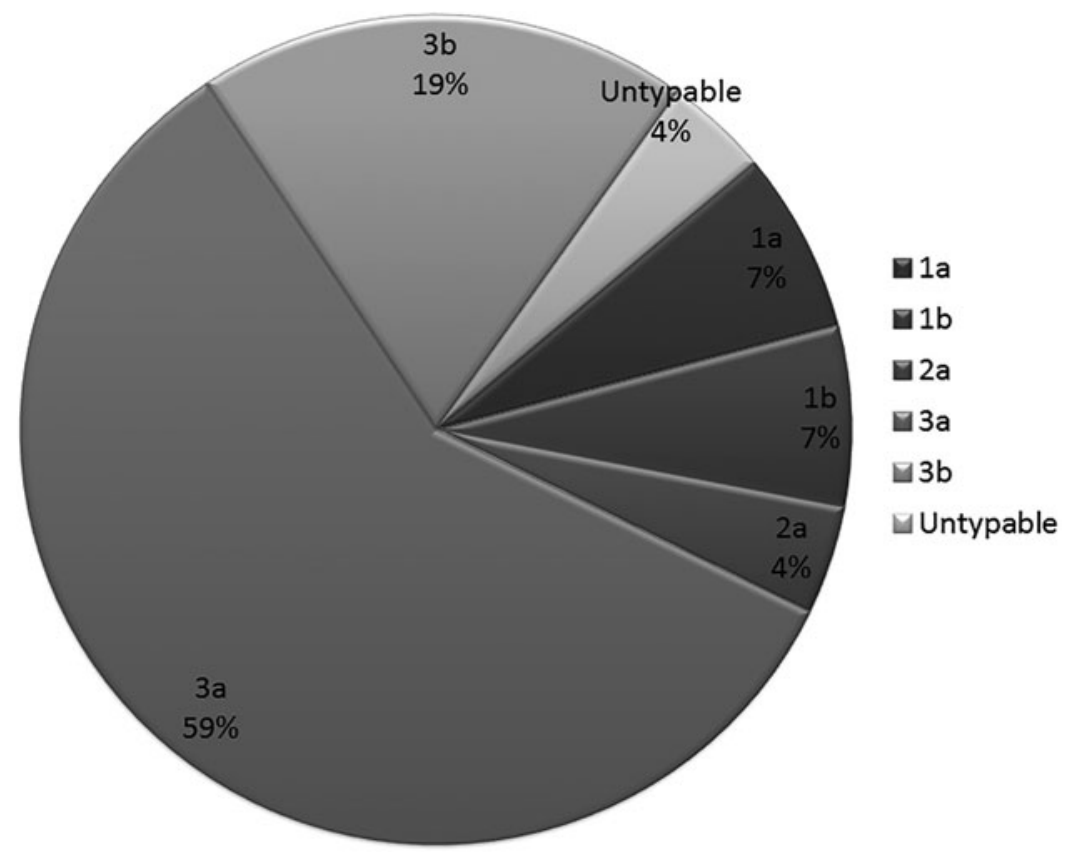

FIG. 7. HCV genotype distribution in Azad Jammu and Kashmir. 
The data assembled and compiled from previous publications about HCV distribution pattern in Pakistan from year 2009 to 2018 allowed us to demonstrate the pattern of HCV genotype infections. Predominance of genotype 3a was observed in this study and the studies conducted in past from Pakistan. Other genotypes following the genotype $3 \mathrm{a}$ were untypable and $3 \mathrm{~b}$. The genotype frequency pattern illustrated in our study was almost similar to the results published by Butt et al. and Umer Mand Iqbal (26,73); some differences might be due to geographical differences. The analysis conducted by Khan was somehow in contrast with our study, which showed genotype $2 \mathrm{a}$ as second most prevalent genotype, whereas in our study, untypable was the most prevalent after genotype $3 a$ (44). It was observed that the incidence of genotype $3 \mathrm{a}$, untypable, and $3 \mathrm{~b}$ is increasing in Pakistan, with decrease in the incidence of genotype $2 \mathrm{a}, 2 \mathrm{~b}$, and $1 \mathrm{a}$.

Very limited data were available about the genotyping in Baluchistan province. The results in this study were comparable with the study conducted in 2009, which showed high prevalence of $1 \mathrm{a}$ and $2 \mathrm{a}$, but according to our analysis, $3 \mathrm{a}$ and untypable were the most prevalent (37). The difference in results might be due to less sample size; so, there is need to conduct more systematic and synchronized genotyping in Baluchistan province of Pakistan.

In all previous studies $(3,13,14,46)$ and this study, 3 a and unclassified genotype are predominant in KPK province. The results reported by Kumar et al. showed that infections with $2 \mathrm{a}(4.1 \%)$ are rare compared to our analysis; frequency of genotype $2 \mathrm{a}$ is $12 \%$. Latest study from 2017 demonstrates an increase in the incidence of mixed genotypes and 1a, which is in contrast with the results of this study (48).

All previous studies correspond well with this analysis, at a point that $3 \mathrm{a}$ is most prevalent in Punjab Province $(2,9,20,21)$. Results of this study showed high frequency of 1a, whereas results published by Aziz et al. $(20,21)$ observed comparatively less frequency. $2 \mathrm{a}$ and $1 \mathrm{~b}$ are less frequent in Punjab province according to this study and past studies. Prevalence of untypable genotype in Punjab is very less compared to other provinces.

$\mathrm{HCV}$ genotyping data of Sindhi patients published in 2014 resemble our findings (12). These analyses demonstrate $3 \mathrm{a}$ as most prevalent genotype, followed by untypable, $3 \mathrm{~b}$, and $1 \mathrm{a}$ in decreasing order $(12,24)$. Conclusions drawn by Shaikh et al. were in contrast with the analysis in this study, which showed $3 \mathrm{a}(50.8 \%)$ as most prevalent, and exceptionally high frequency of untypable (47\%) was observed, followed by $2 \mathrm{a}(1.6 \%)$. All other genotypes were not seen in a total of 120 sample size (68).

The main purpose of HCV therapy is to prevent disease progression, liver cirrhosis, morbidity, and mortality (32). The quality of life of an $\mathrm{HCV}$-infected patient can be improved by selecting a therapy that efficiently eradicates viral RNA from body, achieving high sustained virologic response (SVR), with minimal adverse effects (34). Patient's age, ethnicity, viral load, rapid virologic response (RVR), and viral genotype are the predictive factors for the selection of therapy type and duration (29,76). Genotype identification before treatment is crucial/decisive as treatment of $\mathrm{HCV}$ is purely genotype dependent (27).

The traditional HCV treatment supported the use of standard IFN and PEG-IFN (PEG-IFN alpha 2a or 2b) as a monotherapy or in combination with ribavirin. As Pakistan is a developing country with low health budget, standard IFN with ribavirin was preferred due to its low cost compared to PEG-IFN $(28,36)$. Crespo et al. observed that patients treated with IFN achieved SVR of $53 \%$, but with PEG-IFN, higher SVR of $78 \%$ was observed (30). Idrees and Riazuddin showed that in Pakistan, end-of-treatment response (ETR) is $67 \%$ when treated with ribavirin plus IFN (38). SVR of $77 \%$ was observed, whereas $23 \%$ patient relapsed after the completion of treatment (25). Although antiviral treatments have appreciable SVR rates, it results in several complications. Patients treated with IFN were observed to be suffering from anxiety, depression, and acute psychosis (53), whereas with PEG-IFN, headache, nausea, insomnia, myalgia, and weakness was commonly reported (38). Most common adverse effect of ribavirin noticed was hemolytic anemia, loss of appetite, and indigestion $(51,56)$. Few years back, IFN plus ribavirin with treatment efficacy of $50-81 \%$ SVR was the only choice for HCV treatment, despite its detrimental effects.

New advancements about the HCV life cycle and viral enzymes have led to the development of DAA $(17,33)$. Sofosbuvir is a nucleotide analogue that acts by inhibiting NS5B polymerase (49). It is a potential drug for curing and limiting the spread of viral infections with an SVR of 8095\% (77). Reports published in 2017 have shown exceptionally good results, yielding RVR, ETR, and SVR of $99.5 \%$, $99 \%$, and $98.5 \%$, respectively (69).

The strongest prognostic aspect of the treatment response and efficacy is the genotype of viral HCV. Determination of genotype before selection of a therapy type and duration is necessary, as therapy response is genotype dependent (59). Study conducted by Idrees and Riazuddin (38) concluded the results of SVR achieved when patients of different genotypes were treated with IFN plus Ribavirin. Patients infected with HCV genotype 2 achieved highest SVR of $69.7 \%$, followed by genotype $3(57.3 \%)$; however, genotype 1 achieved lowest SVR of $24.2 \%$ (38). Lam et al. reported that genotype 3 has lower SVR rate $(84 \%)$ than genotype 2 (94\%), when treated with SOF, Sofosbuvir - NS5B inhibitor plus RVR for 24 and 12 weeks, respectively (49). Another study reported the comparison of SVR achieved in patients of genotype 3 and 2 (56\% and 97\%, respectively), when treated with sofosbuvir (65).

\section{Conclusion}

In Pakistan, HCV disease burden is escalating very rapidly, infecting almost 6\% (10 million) of population. This study highlights the HCV genotype distribution pattern in different regions of Pakistan. There were no data available from Gilgit Province and very limited data were available from Baluchistan; so there is a need for more systemized analysis of genotype distribution in these provinces. Genotype determination is crucial for viral eradication and therapy response. For disease management, there is a need to design a treatment achieving high SVR with minimal adverse effects. In Pakistan, the most prevalent genotype is 3a, followed by untypable genotype. Both IFN and sofosbuvir yield good SVR against genotype 3a, but treatment with sofosbuvir has comparatively high SVR, less adverse effects, and more tolerability. 


\section{Author Disclosure Statement}

No competing financial interests exist.

\section{Funding Information}

There is no role of any funding agency related to this study.

\section{References}

1. Afridi S, Naeem M, Hussain A, et al. Prevalence of hepatitis $\mathrm{C}$ virus (HCV) genotypes in Balochistan. Mol Biol Rep 2009;36:1511-1514.

2. Afridi SQ, Ali MM, Awan F, et al. Molecular epidemiology and viral load of $\mathrm{HCV}$ in different regions of Punjab, Pakistan. Virol J 2014;11:24.

3. Afridi SQ, Zahid MN, Shabbir MZ, et al. Prevalence of HCV genotypes in district Mardan. Virol J 2013;10:90.

4. Afzal MS. Hepatitis $C$ virus and interferon-free antiviral therapeutics revolution: implications for Pakistan. Viral Immunol 2017;30:252-257.

5. Afzal MS, and Ahmad I. HCV treatment with Sofosbuvir in Pakistan; current scenario and future perspective. J Gastroenterol Hepatol Res 2018;7:2578-2580.

6. Afzal MS, and Ahmed T. Comparison of HCV prevalence in Pakistan and iran; an insight into future. Hepat Mon 2014; $14: 1$.

7. Afzal MS, Shah ZH, and Ahmed H. Recent HCV genotype changing pattern in the Khyber Pakhtunkhwa province of Pakistan; is it pointing out a forthcoming problem? Braz $\mathbf{J}$ Infect Dis 2016;20:312-313.

8. Afzal MS, Zaidi NUSS, Dubuisson J, et al. Hepatitis C virus capsid protein and intracellular lipids interplay and its association with hepatic steatosis. Hepat Mon 2014;14: e17812.

9. Ahmad W, Ijaz B, Javed FT, et al. HCV genotype distribution and possible transmission risks in Lahore, Pakistan. World J Gastroenterol 2010;16:4321.

10. Ahmed S, Mahmud M, Khan N, et al. Pegylated interferon and ribavirin in $\mathrm{HCV}$ genotype 3 detectable patients after 12 weeks of conventional interferonribavirin treatment. Pak J Gastroenterol 2006;20:58-62.

11. Akhtar N, Bilal M, Rizwan M, et al. Genotypes of hepatitis $\mathrm{C}$ virus in relapsed and non-respondent patients and their response to anti-viral therapy in district Mardan, Khyber Pakhtunkhawa, Pakistan. Asian Pac J Cancer Prev 2015;16: 1037-1040.

12. Akhund AA, Akhtar R, Husain Naqvi SQ, et al. Chronic hepatitis; HCV genotypes in correlation with alanine aminotransferase level in patients in interior of Sindh. Prof Med J 2014;21:450-454.

13. Ali A, Ahmed H, and Idrees M. Molecular epidemiology of hepatitis $\mathrm{C}$ virus genotypes in Khyber Pakhtoonkhaw of Pakistan. Virol J 2010;7:203.

14. Ali S, Ahmad A, Khan RS, et al. Genotyping of HCV RNA reveals that $3 \mathrm{a}$ is the most prevalent genotype in Mardan, Pakistan. Adv Virol 2014;2014:606201.

15. Ali S, Ahmad B, Ali I, et al. Virological response to conventional interferon therapy combined with ribavirin against various HCV genotypes in Khyber Pakhtunkhwa, Pakistan. Asian Pac J Cancer Prev 2016;17:2407-2410.

16. Ali S, Ali I, Azam S, et al. Frequency distribution of HCV genotypes among chronic hepatitis C patients of Khyber Pakhtunkhwa. Virol J 2011;8:193.
17. Andriulli A, Mangia A, Iacobellis A, et al. Meta-analysis: the outcome of anti-viral therapy in $\mathrm{HCV}$ genotype 2 and genotype 3 infected patients with chronic hepatitis. Aliment Pharmacol Ther 2008;28:397-404.

18. Attaullah $\mathrm{S}$, Khan $\mathrm{S}$, and Ali I. Hepatitis $\mathrm{C}$ virus genotypes in Pakistan: a systemic review. Virol J 2011;8:433.

19. Attaullah S, Khan S, and Zahid M. Heterogeneous distribution of HCV genotypes and growing menace of mixed $\mathrm{HCV}$ infection in blood recipients in Khyber Pakhtunkhwa. Braz J Infect Dis 2017;21:489-490.

20. Aziz H, Raza A, and Irfan J. Optimum predictors of therapeutic outcome in HCV patients in Pakistan. J Med Virol 2016;88:100-108.

21. Aziz H, Raza A, Murtaza S, et al. Molecular epidemiology of hepatitis $\mathrm{C}$ virus genotypes in different geographical regions of Punjab Province in Pakistan and a phylogenetic analysis. Int J Infect Dis 2013;17:e247-e253.

22. Bashir MF, Haider MS, Rashid N, et al. Distribution of hepatitis $\mathrm{C}$ virus (HCV) genotypes in different remote cities of Pakistan. Afr J Microbiol Res 2012;6:47474751.

23. Bashir T, Asim M, Ahsan M, et al. A case report: patient with the history of hepatitis $\mathrm{C}$ virus. J Antivir Antiretrovir 2017;9:055-057.

24. Bhatti S, and Manzoor S. Molecular epidemiology and clinical features of hepatitis $\mathrm{C}$ virus (HCV) in epidemic areas of interior Sindh, Pakistan. Pak J Med Sci 2016;32: 1279.

25. Bukhari MM. Standard interferon and ribavirin response in patients with chronic hepatitis C. J Rawalpindi Med Coll 2013;17:297-299.

26. Butt S, Idrees $\mathrm{M}, \mathrm{Akbar} \mathrm{H}$, et al. The changing epidemiology pattern and frequency distribution of hepatitis $\mathrm{C}$ virus in Pakistan. Infect Genet Evol 2010;10:595-600.

27. Capileno YA, Van den Bergh R, Donchunk D, et al. Management of chronic hepatitis $\mathrm{C}$ at a primary health clinic in the high-burden context of Karachi, Pakistan. PLoS One 2017;12:e175562.

28. Castillo I, Bartolomé J, Quiroga JA, et al. Diagnosis of occult hepatitis $\mathrm{C}$ without the need for a liver biopsy. J Med Virol 2010;82:1554-1559.

29. Contreras AM, Ochoa-Jiménez RJ, Celis A, et al. High antibody level: an accurate serologic marker of viremia in asymptomatic people with hepatitis $\mathrm{C}$ infection. Transfusion 2010;50:1335-1343.

30. Crespo M, Esteban JI, Ribera E, et al. Utility of week-4 viral response to tailor treatment duration in hepatitis $\mathrm{C}$ virus genotype 3/HIV co-infected patients. AIDS 2007; 21:477-481.

31. Cuevas JM, González-Candelas F, Moya A, et al. Effect of ribavirin on the mutation rate and spectrum of hepatitis C virus in vivo. J Virol 2009;83:5760-5764.

32. Dipiro J, Talbert R, Yee G, et al. 2008 PharmacotherapyA Pathophysiologic Approach. 7th ed. New York: Mc Graw Hill Medical, 2008.

33. Ge D, Fellay J, Thompson A, et al. Genetic variation in IL28B predicts hepatitis C treatment-induced viral clearance. Nature 2009;461:399-401.

34. Ghany MG, Strader DB, Thomas DL, et al. Diagnosis, management, and treatment of hepatitis C: an update. Hepatology 2009;49:1335-1374.

35. Gray RR, Strickland SL, Veras NM, et al. Unexpected maintenance of hepatitis $\mathrm{C}$ viral diversity following liver transplantation. J Virol 2012;86:8432-8439. 
36. Hamid S, Umar M, Alam A, et al. PSG consensus statement on management of hepatitis $\mathrm{C}$ virus infection-2003. J Pak Med Assoc 2004;54:146.

37. Idrees $M$, and Riazuddin S. Frequency distribution of hepatitis $\mathrm{C}$ virus genotypes in different geographical regions of Pakistan and their possible routes of transmission. BMC Infect Dis 2008;8:69.

38. Idrees M, and Riazuddin S. A study of best positive predictors for sustained virologic response to interferon alpha plus ribavirin therapy in naive chronic hepatitis $\mathrm{C}$ patients. BMC Gastroenterol 2009;9:5.

39. Imran M, Manzoor S, Azam S, et al. Genetic variant of IL 28B rs12979860, as predictive marker of interferon-based therapy in Pakistani population. APMIS 2015;123:342 349.

40. Imran M, Manzoor S, Khattak NM, et al. Correlation of OAS1 gene polymorphism at exon 7 splice accepter site with interferon-based therapy of $\mathrm{HCV}$ infection in Pakistan. Viral Immunol 2014;27:105-111.

41. Inamullah I, Idrees $\mathrm{M}$, Ahmed $\mathrm{H}$, et al. Hepatitis $\mathrm{C}$ virus genotypes circulating in district Swat of Khyber Pakhtoonkhaw, Pakistan. Virol J 2011;8:16.

42. Khan AW, Nasim Z, Zahir F, et al. Untypeable hepatitis C virus subtypes in Pakistan: a neglected section. Acta Microbiol Immunol Hung 2016;63:427-431.

43. Khan AW, Nawab S, Nasim Z, et al. Pattern of hepatitis C virus genotypes and subtypes circulating in war-stricken Khyber Pakhtunkhwa, Pakistan: review of published literature. Asian Pac J Trop Med 2017;10:1037-1042.

44. Khan N, Akmal M, Hayat M, et al. Geographic distribution of hepatitis C virus genotypes in Pakistan. Hepat Mon 2014; 14:e20299.

45. Khan S, Attaullah S, Ali I, et al. Rising burden of hepatitis C virus in hemodialysis patients. Virol J 2011;8:438.

46. Khan S. Molecular epidemiology of hepatitis c virus infection in Khyber Pakhtunkhwa. Doctoral dissertation, Kohat University of Science and Technology, Khyber Pakhtunkhwa, Pakistan, 2013. http://prr.hec.gov.pk/jspui/handle/123456789/ 2322 (accessed September 24, 2019).

47. Khan S, Attaullah S, Ayaz S, et al. Molecular epidemiology of HCV among health care workers of Khyber Pakhtunkhwa. Virol J 2011;8:1.

48. Kumar T, Ahmad N, Hayat MK, et al. Prevalence and genotypic distribution of hepatitis $\mathrm{C}$ virus in Peshawar KPK, Pakistan. Hayati J Biosci 2017;24:22-25.

49. Lam BP, Jeffers T, Younoszai Z, et al. The changing landscape of hepatitis $C$ virus therapy: focus on interferon-free treatment. Ther Adv Gastroenterol 2015; 8:298-312.

50. Mahmood K, Mohammad N, and Abidullah A. Genotype variation of hepatitis $\mathrm{C}$ virus in district Buner Swat. J Ayub Med Coll Abbottabad 2011;23:18-21.

51. Manns MP, McHutchison JG, Gordon SC, et al. Peginterferon alfa- $2 \mathrm{~b}$ plus ribavirin compared with interferon alfa-2b plus ribavirin for initial treatment of chronic hepatitis C: a randomised trial. Lancet 2001;358:958-965.

52. Messina JP, Humphreys I, Flaxman A, et al. Global distribution and prevalence of hepatitis $\mathrm{C}$ virus genotypes. Hepatology 2015;61:77-87.

53. Munir S, Saleem S, Idrees M, et al. Hepatitis C treatment: current and future perspectives. Virol J 2010;7:296.
54. Nabi SG, Zaffar G, Sheikh NI, et al. Hepatitis C virus genotypes: a plausible association with viral loads. Indian $\mathrm{J}$ Pathol Microbiol 2013;56:384.

55. Ohno O, Mizokami M, Wu R-R, et al. New hepatitis C virus (HCV) genotyping system that allows for identification of HCV genotypes 1a, 1b, 2a, 2b, 3a, 3b, 4, 5a, and 6a. J Clin Microbiol 1997;35:201-207.

56. Ohto $\mathrm{H}$, Terazawa $\mathrm{S}$, Sasaki $\mathrm{N}$, et al. Transmission of hepatitis $\mathrm{C}$ virus from mothers to infants. N Engl J Med 1994;330:744-750.

57. Petruzziello A. Suppl-1, M3: epidemiology of hepatitis $\mathrm{B}$ virus (HBV) and hepatitis $\mathrm{C}$ virus $(\mathrm{HCV})$ related hepatocellular carcinoma. Open Virol J 2018;12:26.

58. Petruzziello A, Loquercio G, Sabatino R, et al. Prevalence of hepatitis $\mathrm{C}$ virus genotypes in nine selected European countries: a systematic review. J Clin Lab Anal 2019;33: e22876.

59. Petruzziello A, Marigliano S, Loquercio G, et al. Global epidemiology of hepatitis $\mathrm{C}$ virus infection: an up-date of the distribution and circulation of hepatitis $\mathrm{C}$ virus genotypes. World J Gastroenterol 2016;22:7824.

60. Petruzziello A, Marigliano S, Loquercio G, et al. Hepatitis $\mathrm{C}$ virus (HCV) genotypes distribution among hepatocellular carcinoma patients in Southern Italy: a three year retrospective study. Infect Agents Cancer 2017;12:52.

61. Rauf A, Nadeem MS, Ali A, et al. Prevalence of hepatitis $\mathrm{B}$ and $\mathrm{C}$ in internally displaced persons of war against terrorism in Swat, Pakistan. Eur J Public Health 2010;21: 638-642.

62. Rauf A, Nadeem MS, Arshad M, et al. Prevalence of hepatitis $\mathrm{B}$ and $\mathrm{C}$ virus in the general population of hill surang area, Azad Jammu and Kashmir, Pakistan. Pak J Zool 2013;45:543-548.

63. Raza H, Ahmad T, and Afzal MS. HCV, interferon therapy response, direct acting antiviral therapy revolution and Pakistan: future perspectives. Asian Pac J Cancer Prev 2015;16:5583-5584.

64. Riaz S, Bashir MF, Haider S, et al. Association of genotypes with viral load and biochemical markers in HCV-infected Sindhi patients. Braz J Microbiol 2016;47: 980-986.

65. Rodriguez-Torres M, Lawitz E, Kowdley KV, et al. Sofosbuvir (GS-7977) plus peginterferon/ribavirin in treatmentnaive patients with HCV genotype 1: a randomized, 28-day, dose-ranging trial. J Hepatol 2013;58:663-668.

66. Saleha S, Kamal A, Ullah F, et al. Prevalence of hepatitis C virus genotypes in district Bannu, Khyber Pakhtunkhwa, Pakistan. Hepat Res Treat 2014;2014:165826.

67. Shah HA, Jafri W, Malik I, et al. Hepatitis C virus (HCV) genotypes and chronic liver disease in Pakistan. J Gastroenterol Hepatol 1997;12:758-761.

68. Shaikh N, Waryah AM, Devrajani BR, et al. IL28B rs12980275 polymorphism shows association with response to treatment in Pakistani patients with chronic hepatitis C. J Med Virol 2015;87:814-820.

69. Siddique MS, Shoaib S, Saad A, et al. Rapid virological and end treatment response of patients treated with sofosbuvir in chronic hepatitis C. Pak J Med Sci 2017;33:813.

70. Sili U, Kaya A, Aydin S, et al. HCV-specific lymphocyte responses in individuals with positive anti-HCV but negative HCV-RNA. J Clin Virol 2015;67:73-77. 
71. Smith DB, Pathirana S, Davidson F, et al. The origin of hepatitis C virus genotypes. J Gen Virol 1997;78:321328.

72. Tariq S, Batool Z, Jahanzeb V, et al. Hepatitis C virus genotype distribution amongst $\mathrm{HCV}$ positive patients presenting at a private tertiary care hospital of Peshawar, Khyber Pakhtunkhwa. J Rehman Med Inst 2017;2:33-39.

73. Umer Mand Iqbal $M$. Hepatitis $C$ virus prevalence and genotype distribution in Pakistan: comprehensive review of recent data. World J Gastroenterol 2016;22:1684.

74. ur Rehman L, Ullah I, Ali I, et al. Active hepatitis C infection and HCV genotypes prevalent among the IDUs of Khyber Pakhtunkhwa. Virol J 2011;8:327.

75. Waheed Y, Shafi T, Safi SZ, et al. Hepatitis C virus in Pakistan: a systematic review of prevalence, genotypes and risk factors. World J Gastroenterol 2009;15:5647.

76. Welfman M, Brotodihardjo A, and Crewe E. Coinfection with hepatitis $\mathrm{B}$ and $\mathrm{C}, \mathrm{C}$ and $\mathrm{D}$ viruses result in severe chronic liver disease and responds poorly to interferon. J Viral Hept 1995;2:39-45.

77. World Health Organization. 2016 Guidelines for the Screening, Care and Treatment of Persons with Chronic Hepatitis C Infection. World Health Organization, Geneva, Switzerland.
78. Yahya KM, Khan RR, Aziz U, et al. Frequency of various hepatitis $\mathrm{C}$ virus (HCV) genotypes in Faisalabad and surrounding districts. JUMDC 2013;4:57-62.

79. Yu JW, Wang GQ, Sun LJ, et al. Predictive value of rapid virological response and early virological response on sustained virological response in HCV patients treated with pegylated interferon $\alpha-2 \mathrm{a}$ and ribavirin. J Gastroenterol Hepatol 2007;22:832-836.

80. Zafar A, Imran M, Zahoor S, et al. Prevalence and treatment of untypable $\mathrm{HCV}$ variants in different districts of Punjab, Pakistan. Viral Immunol 2018;31:426-432.

81. Zein NN. Clinical significance of hepatitis $\mathrm{C}$ virus genotypes. Clin Microbiol Rev 2000;13:223-235.

Address correspondence to: Dr. Muhammad Sohail Afzal Department of Life Sciences School of Science

University of Management and Technology (UMT) Lahore 54770

Pakistan

E-mail: sohail.ncvi@gmail.com 